\title{
Comparative efficacy of indigenous plant extracts and a synthetic insecticide for the management of tomato fruit worm (Helicoverpa armigera Hub.) and their effect on natural enemies in tomato crop
}

\author{
Amjad Usman*, Mian Imad Ali, Maqsood Shah, Fazal e Amin and \\ Jawad Sarwar \\ Department of Entomology, University of Agriculture, Peshawar-Pakistan \\ *Corresponding author's email: amjadusman@aup.edu.pk \\ Citation \\ Amjad Usman, Mian Imad Ali, Maqsood Shah, Fazal e Amin and Jawad Sarwar. Comparative efficacy of \\ indigenous plant extracts and a synthetic insecticide for the management of tomato fruit worm (Helicoverpa \\ armigera Hub.) and their effect on natural enemies in tomato crop. Pure and Applied Biology. Vol. 7, Issue 3, \\ pp1014-1020. http://dx.doi.org/10.19045/bspab.2018.700120
}

\begin{tabular}{llll}
\hline \hline Received: 17/04/2018 & Revised: 09/07/2018 & Accepted: 20/07/2018 & Online First: 23/07/2018 \\
\hline \hline
\end{tabular}

\section{Abstract}

Efficacy of five botanical extracts (eucalyptus, bakayan, chilli, thyme and onion extract) and synthetic insecticide (Steward 150 EC) was evaluated against $H$. armigera and its associated natural enemies under field conditions during 2014, followed Randomize Complete Block Design with three replications. Results revealed that all the tested botanicals and insecticide were found effective in controlling the tomato fruit worm infestation as compared to control. Among all the tested spray materials, Steward $150 \mathrm{EC}$ was found the most effective in reducing $H$. armigera larval infestation (61.01\%) followed by bakayan extract $(44.49 \%)$. However, the steward $150 \mathrm{EC}$ was comparatively more toxic to the natural enemies than botanicals. Fruit infestation was minimum in Steward tested plots and maximum in control on weight basis and on number basis $10.53 \%$ and $10.29 \%$ and $30.88 \%$ and $29.11 \%$ respectively. Similarly, Steward treated plot yielded the highest $\left(9564 \mathrm{~kg} \mathrm{ha}^{-1}\right)$ and control yielded the lowest $\left(5487 \mathrm{~kg} \mathrm{ha}^{-1}\right)$. It was concluded that Steward $150 \mathrm{EC}$ was the most effective in managing fruit worm infestation and hence resulting the minimum fruit damage and consequently enhanced the yield of tomato. However, the synthetic insecticide was extremely toxic to the natural enemies. Furthermore, eucalyptus, chilli, onion and thyme extract also showed better results than control in term of pest reduction and were comparatively safe to the natural enemies, Hence these botanicals should be included in IPM program for the suitable management of $H$. armigera associated with tomato crop.

Keywords: Botanical extracts; Helicoverpa armigera infestation; Natural enemies; Percent reduction; Synthetic insecticide

\section{Introduction}

Tomato fruit worm (H. armigera Hub.) is one of the devastating pest of tomato resulting in considerable yield losses i.e. $32-53 \%$ annually [1]. Initially pest starts feeding on leaves, flowers and finally bore into tomato fruits, making them unfit for human consumption and also reduce its market value [2]. Being a polyphagous pest, annual loss of approximately 5 billion US 
dollars has been attributed to $H$. armigera worldwide [3]. To deal with this potential and notorious pest, $85 \%$ of the word insecticide is used to manage this pest [4]. This incredible use of synthetic insecticide has led to the problem of pest resurgence, insecticidal resistance in insects, environmental pollution, health problems, decimation of useful fauna and the increased cost of pest controls as well [5]. In order to address all these issues, it has become imperative to explore the substitutes of these toxic insecticides to keep the $H$. armigera population below injury level and have no harmful effect on biocontrol agents [6].

One such alternate is the use of plant extracts. The use of plant extracts has been given major emphasis in IPM Programme. Compared to other commonly used synthetic insecticides, plant extracts are safe for both the pesticide user and consumer of the treated crop as well as to non-target animals and humans.

Mostly the farmers rely on conventional synthetic chemicals to control insect pest and little attention has been made to explore the indigenous fauna having insecticidal properties that is ecofriendly and safe for nature enemies. The concept of botanicals extracts is not particularly new and some important practical progress has been made in other crops/ insects. Hence, an attempt has made to evaluate the efficacy of indigenous plant extracts i-e. Melia azedarach, Thymus volgaris, Eucalyptus tereticornis, Allium cepa and Capsicum annum on $H$. armigera and its associated natural enemies as alternative to synthetic insecticide for the sustainable management of tomato fruit.

\section{Materials and methods}

The current experiment was carried out at New Developmental Farm (NDF) of The University of Agriculture, Peshawar during spring 2014, to evaluate the efficacy of various indigenous plant against tomato fruit worm (H. armigera) and its associated natural enemies in tomato crop.

\section{Field layout and experimental design}

Seedlings of tomato variety (Riogrande) were transplanted in $2^{\text {nd }}$ week of March followed randomized complete block design (RCBD) with three replications. Plot size was $1.5 \times 3$ square meter. Plant to plant and row to row distance was maintained $45 \mathrm{~cm}$ and $90 \mathrm{~cm}$ respectively. Standard agronomic and cultural practices were applied uniformly to all experimental plots.

\section{Treatments and its application}

All the plant extracts and insecticide (steward) were sprayed twice by Knap Sack sprayer at 15 days interval. At the time of spray, polythene sheet was hanged around each plot to protect the adjacent plots from the drift effect of spray application (Table $1)$.

Table 1. Detail of different botanical extracts and a synthetic insecticide used in the experiment

\begin{tabular}{|c|c|c|c|}
\hline Treatments & $\begin{array}{c}\text { Treatments } \\
\text { (common name) }\end{array}$ & Technical Name & Concentration / dose \\
\hline 1 & Eucalyptus & Eucalyptus tereticornis & $5 \%$ \\
\hline 2 & Bakayan & Melia azedarach & $5 \%$ \\
\hline 3 & Chilli & Capsicum annum & $5 \%$ \\
\hline 4 & Thyme & Thymus volgaris & $5 \%$ \\
\hline 5 & Onion & Allium cepa & $5 \%$ \\
\hline 6 & Steward 150 EC & Indoxicarb & $250 \mathrm{ml} \mathrm{ha}^{-1}$ \\
\hline 7 & Control & - & - \\
\hline
\end{tabular}

\section{Extract preparation}

The above mentioned tested botanicals were collected from the local area, washed and dried under shade for 7 days. The dried material of each plant parts was grinded into fine powder separately. Ten percent $(10 \%)$ stock solution of each plant extract was prepared by mixing $100 \mathrm{~g}$ powder in 1 liter of water in a conical flask. The mixture was thoroughly shaken, left for $24 \mathrm{~h}$ and 
filtered through muslin cloth to remove the impurities. 5\% concentration for field application was prepared from the stock solution.

\section{Data collection \\ H. armigera larvae plant ${ }^{-1}$}

Data on $H$. armigera larval population were recorded on randomly selected 5 plants in each plot, 24 hours before spray application and then after 24 hours, 48 hours, 72 hours and 7 days of spray application. The data were then converted into percent larval reduction using [7] formula as under:

Per cent reduction in population $=$

$\left[1-\underline{T}_{a} \underline{T_{b}} \mathrm{C}_{b}\right] \times 100$

$\mathrm{T}_{\mathrm{b}} \times \mathrm{C}_{\mathrm{a}}$

Where,

$\mathrm{Ta}=$ insects population after spray

application

$\mathrm{Tb}=$ insects population before spray

application

$\mathrm{Ca}=$ insects population in control plot after spray application

$\mathrm{Cb}=$ insects population in control plot after spray application

\section{Natural enemies population plant ${ }^{-1}$}

Predators (green lace wing and lady bird beetle) were also counted on randomly selected 5 plants in each plot, 24 hours before spray application and then after 24 hours, 48 hours, 72 hours and 7 days of spray application. The data were then converted into percent reduction in predators population using [7] formula as mentioned earlier

\section{Percent fruit damage (weight and number basis)}

Fruits damaged by $H$. armigera larvae on weight and number basis were recorded at each picking by counting and weighting sound and infested fruit. Percent fruit damage was calculated using following formula as suggested by [8].

$\%$ damaged fruits (weight basis) $=$

Weight of damaged fruits x 100

Total weight of tomato

$\%$ damaged fruits (number basis) $=$ Number of damaged fruits x 100

Total number of tomato

\section{Yield}

Yield in different treatments was recorded at each picking from net plot area. Total yield was calculated by adding the yield from all picking for each treatment and then converted in to yield per hectares with the following formula:

Yield $\left(\mathrm{kg} \mathrm{ha}^{-1}\right)=\frac{\text { Yield plot }}{-1} \times 10000$

\section{Statistical analysis}

All the above parameters were subjected to the analysis of variance and means were separated using LSD test at 5\% level of significance.

\section{Results and discussion}

\section{$H$. armigera larval infestation}

Results on efficacy of different botanicals and a synthetic insecticide against $H$. armigera larval infestation showed that all the tested treatments were significantly superior in reducing the larval population (Table 2). However, two sprays application of Steward was found to be the most effective after $24 \mathrm{hr}, 48 \mathrm{hr}, 48 \mathrm{hr}$ and 7 days with maximum mean reduction $(61.01 \%)$ in the larval population of $H$. armigera followed by Bakayan extract with a total larval reduction of $44.49 \%$. Our current results are previously endorsed by [9] who found $73.25-76.65 \%$ reduction in larval population under field conditions after first and second spray of indoxacarb at recommended dose respectively. Similar finding has also been reported by [10] who stated that synthetic insecticide was more effective than botanicals. [11] also reported that steward was much effective when applied against early instars larvae of $H$. armigera and hence maximum mortality of the targeted pest was recorded in 24-48 hours after spray application. Similarly [12] found that steward remain effective against different instars of $H$. armigera and 24-48 hours are sufficient enough to kill early stages of $H$. armigera. However, present findings (Table 2) showed that maximum mortality was recorded after 72 hours of spray application, might be due to variation in the dose and experimental condition. It can be seen that spray application of 
euclyptus, onion, chilli and thyme extract were equally effective and efficiently reduce the pest population with mean larval reduction of $32.50 \%, 32.05 \%, 31.63$ and $30.29 \%$ respectively. The present finding is in accordance with the findings of $[13,14]$. Onion extracts produces a pungent alliaceous which probably is responsible for its pest repellent attribute. Similarly [15] also assumed the anti-feeding effect of garlic and onion reduced the ability of the

Table 2. Effect of plant extract and synthetic insecticide on $\boldsymbol{H}$. armigera larvae infesting tomato crop during 2014

\begin{tabular}{|c|c|c|c|c|c|c|c|c|c|}
\hline \multirow{3}{*}{ Treatments } & \multicolumn{9}{|c|}{ \% reduction in larval population after spray application } \\
\hline & \multicolumn{9}{|c|}{$1^{\text {st }}$ Spray $\quad 2^{\text {nd }}$ Spray } \\
\hline & 24 hours & 48 hours & 72 hours & 7 days & 24 hours & 48 hours & 72 hours & 7 days & Mean \\
\hline Eucalyptus extract & $22.58 \mathrm{~cd}$ & $20.22 \mathrm{c}$ & $43.53 \mathrm{c}$ & $37.66 \mathrm{~b}$ & $27.46 \mathrm{c}$ & $43.98 \mathrm{bc}$ & $55.43 \mathrm{c}$ & $9.15 \mathrm{~d}$ & $32.50 \mathrm{c}$ \\
\hline Bakayan extract & $31.36 \mathrm{~b}$ & $37.16 \mathrm{~b}$ & $53.39 \mathrm{~b}$ & $40.33 \mathrm{~b}$ & $34.29 \mathrm{~b}$ & $46.52 \mathrm{~b}$ & $80.03 \mathrm{a}$ & $32.72 \mathrm{~b}$ & $44.49 \mathrm{~b}$ \\
\hline Chilli extract & $26.77 \mathrm{bc}$ & $22.39 \mathrm{c}$ & $42.72 \mathrm{c}$ & $28.66 \mathrm{c}$ & $22.11 \mathrm{~d}$ & $39.95 \mathrm{~cd}$ & $44.51 \mathrm{~d}$ & $26.02 \mathrm{c}$ & $31.63 \mathrm{c}$ \\
\hline Thyme extract & $19.97 \mathrm{~d}$ & $27.41 \mathrm{bc}$ & $44.03 \mathrm{c}$ & $30.76 \mathrm{c}$ & $20.87 \mathrm{~d}$ & $34.12 \mathrm{de}$ & $58.14 \mathrm{c}$ & $6.95 \mathrm{~d}$ & $30.29 \mathrm{c}$ \\
\hline Onion extract & $25.44 \mathrm{c}$ & 26.18 bc & $46.23 \mathrm{c}$ & $29.66 \mathrm{c}$ & $24.09 \mathrm{~cd}$ & $32.65 \mathrm{e}$ & $46.58 \mathrm{~d}$ & $25.45 \mathrm{c}$ & $32.05 \mathrm{c}$ \\
\hline Steward & $51.20 \mathrm{a}$ & $62.40 \mathrm{a}$ & $76.70 \mathrm{a}$ & $62.00 \mathrm{a}$ & $53.10 \mathrm{a}$ & $69.45 \mathrm{a}$ & $72.33 \mathrm{~b}$ & $40.91 \mathrm{a}$ & $61.01 \mathrm{a}$ \\
\hline LSD $_{0.05}$ & 5.304 & 11.578 & 4.406 & 4.6873 & 4.350 & 5.913 & 5.528 & 3.743 & 2.880 \\
\hline
\end{tabular}

Means in columns with different letters are significantly different at $p=0.05$ using LSD Test

\section{Natural enemies population}

In the present study, two natural enemies (Green lacewing and ladybird beetle) were found to be associated with tomato crop. The presences of these natural enemies in the field play an important role in the population fluctuation of the pest. Previous studies showed that steward is safe and selective insecticides [18]. However, table 3 clearly indicated that both natural enemies were significantly affected by the tested treatment applications. In both spray application, insecticide steward found more toxic to both the natural enemies (ladybird beetle and green lacewing) with mean percent reduction of $58.87 \%$ and $44.61 \%$ respectively. Similar finding has also been reported by $[19,20]$ that Steward found from slight to moderate toxic against the green lacewing (Chrysoperla carnea) (68.8-84.8\% mortality). Similarly, [21, 22] revealed that Steward significantly reduced number of predators in field and is slightly toxic to the egg parasitoid Trichogramma chilonis as well. However, all the tested botanicals were comparatively least toxic insects or cutworms to feed. [16] reported that Azadirachtin-based compounds have insecticidal, feeding deterrent, repellent, antioviposition, and physiological properties such as are survival, longevity, molting and reproduction. Similarly thyme contained high amounts of thymol, a monoterpene phenol that binds to postsynaptic GABA receptors associated with chloride channels in insects [17]. and found statistically at par with each other. However, based on mean percent reduction, Chilli extract found relatively safer than other tested botanicals with minimum reduction of $16.64 \%$ and $20.33 \%$ in ladybird beetle and green lace wing population respectively. Present finding showed that steward was very effective and gave maximum mortality of the target pest (Table 2). However, it was slightly toxic to the natural enemies as presented in (Table 3 ). The present study indicated that two spray application of insecticide steward significantly reduced both the predators' population in tomato crop as compared with botanicals. It is clear from this study that botanical extract reduce insect pest infestation and is comparatively safe to the natural enemies. The present findings are in agreement with [23] who found that botanicals (neem) significantly reduced insect pest infestation. Similarly, in the present study predators population was significantly higher in botanicals treated plots as compared to synthetic insecticide, indicating that neem insecticide was 
comparatively less harmful to predators. Similarly, [24] evaluated a formulation of neem against two Coccinelid predators i.e.
M. sexmaculta and $V$. vincta on okra and found all formulations relatively safer than synthetic insecticide.

Table 3. Effect of plant extracts and synthetic insecticide on predators population post spray application during 2014

\begin{tabular}{|c|c|c|c|c|c|c|}
\hline \multirow{2}{*}{ Treatments } & \multicolumn{4}{|c|}{ Mean \% reduction in predators population after spray application } \\
\cline { 2 - 7 } & \multicolumn{2}{|c|}{ Ladybird beetle } \\
\hline & $\mathbf{1}^{\text {st }}$ spray & $\mathbf{2}^{\text {nd }}$ spray & Mean & $\mathbf{1}^{\text {st }}$ spray & $2^{\text {nd }}$ spray & Mean \\
\hline Eucalyptus extract & $12.61 \mathrm{~b}$ & $24.26 \mathrm{bc}$ & $18.44 \mathrm{c}$ & $28.76 \mathrm{~b}$ & $21.05 \mathrm{bc}$ & $24.90 \mathrm{~b}$ \\
\hline Bakayan extract & $34.70 \mathrm{~b}$ & $31.27 \mathrm{~b}$ & $32.98 \mathrm{~b}$ & $26.24 \mathrm{~b}$ & $23.85 \mathrm{bc}$ & $25.05 \mathrm{~b}$ \\
\hline Chilli extract & $18.70 \mathrm{~b}$ & $14.57 \mathrm{c}$ & $16.64 \mathrm{c}$ & $21.43 \mathrm{~b}$ & $19.23 \mathrm{c}$ & $20.33 \mathrm{~b}$ \\
\hline Thyme extract & $34.79 \mathrm{~b}$ & $25.05 \mathrm{bc}$ & $30.09 \mathrm{bc}$ & $25.65 \mathrm{~b}$ & $22.64 \mathrm{bc}$ & $24.15 \mathrm{~b}$ \\
\hline Onion extract & $29.03 \mathrm{~b}$ & $25.05 \mathrm{bc}$ & $27.04 \mathrm{bc}$ & $16.66 \mathrm{~b}$ & $29.33 \mathrm{~b}$ & $23.00 \mathrm{~b}$ \\
\hline Steward 150 EC & $59.56 \mathrm{a}$ & $58.16 \mathrm{a}$ & $58.87 \mathrm{a}$ & $46.06 \mathrm{a}$ & $43.16 \mathrm{a}$ & $44.615 \mathrm{a}$ \\
\hline LSD $\mathbf{0 . 0 5}$ & $\mathbf{2 2 . 2 4 3}$ & $\mathbf{1 4 . 1 4 2}$ & $\mathbf{1 4 . 0 0 0}$ & $\mathbf{1 6 . 1 2 1}$ & $\mathbf{9 . 4 3 5}$ & $\mathbf{9 . 7 2 5}$ \\
\hline
\end{tabular}

Means in columns with different letters are significantly different at $\mathrm{p}=0.05$ using LSD Test

\section{Percent fruit infestation}

Results on fruits infestation by $H$. armigera larvae showed significant variation in tomato (Table 4). Fruit damage was lowest (on weight as well as on number basis) in Steward treated plot $10.29 \%$ and $10.53 \%$ respectively and highest in control with $30.88 \%$ and $29.11 \%$ respectively. Similarly among the botanicals, Bakayain extract was found the second best treatment with $14.58 \%$ fruit damage on weight basis and $15.38 \%$ on number basis followed eucalyptus and onion extract. While thyme extract proved least effective with high fruit damage as compared to the rest of botanicals. Steward was the most effective, resulting in significant decrease in fruit damage over control on weight basis $(66.67 \%)$ and on number basis $(63.82 \%)$ followed by Bakayan extract, while the thyme extract found to be the least effective in reducing the fruit damage $18.20 \%$ and $20.85 \%$ on weight and number basis respectively (Table 4). Similar finding has also been reported by [10] that synthetic insecticide was found superior over botanicals when evaluated against tomato fruit worm. Present study also showed that plant with highest larval infestation had highest degree of fruit damage and vice versa. Our results are in agreement with [8] that high larval infestation resulting high fruit infestation. Similarly, [25] reported that fruit worm infestation could cause serious damage to tomato by boring into the fruits thereby reducing the fruit weight, yield and market value as a result of larval feeding within the fruit contents. Thus the reduction of $H$. armigera larval infestation subsequently led to a reduction in damaged fruit.

\section{Yield (kg ha-1)}

Table 5 shows that tomato yield was significantly affected by tested botanical extracts as well as synthetic insecticide. Highest $\left(9564 \mathrm{~kg} \mathrm{ha}^{-1}\right.$ ) tomato yield was recorded in case of steward treated plots with maximum $(74.30 \%)$ increase in tomato yield over control plots. It was followed eucalyptus extract $\left(8359 \mathrm{~kg} \mathrm{hac}^{-}\right.$ $\left.{ }^{1}\right)$, bakayain extract $\left(8076 \mathrm{~kg} \mathrm{ha}^{-1}\right)$, chilli extract $\left(7512 \mathrm{~kg} \mathrm{ha}^{-1}\right)$, onion extract $(7102$ $\left.\mathrm{kg} \mathrm{ha}^{-1}\right)$ and thyme extract $\left(6410 \mathrm{~kg} \mathrm{ha}^{-1}\right)$ with $52.34 \%, 47.18 \%, 36.90$ and $29.42 \%$ increase in yield over control respectively. Similarly, the lowest yield $\left(5487 \mathrm{~kg} \mathrm{ha}^{-1}\right.$ ) was recorded in control plots. This variation in yield may be due to the different level of larval infestation after the application of different spray application. It has also been observed that the pest initially fed on fresh tender leaves, flower and later on entered into tomato fruits which ultimately affected fruit yield. Results clearly indicate that plots with lowest pest larval population yielded better. While lowest yield was obtained in control plot because of the highest $H$. armigera larval 
population. The present finding is also in agreement with those of [8] that profitable fruit yield was significantly greater in plots

sprayed with selective insecticides compared to botanical extract and biocontrol agent.

Table 4. Effect of botanical extracts and synthetic insecticide on infestation level of tomato by $H$. armigera larva during 2014

\begin{tabular}{|c|c|c|c|c|}
\hline Treatments & $\begin{array}{c}\text { \% fruit infestation } \\
\text { (weight) }\end{array}$ & $\begin{array}{c}\text { \%decrease over } \\
\text { control } \\
\text { (weight) }\end{array}$ & $\begin{array}{c}\text { \% fruit } \\
\text { infestation } \\
\text { (number) }\end{array}$ & $\begin{array}{c}\text { \% decrease } \\
\text { over control } \\
\text { (number) }\end{array}$ \\
\hline Eucalyptus extract & $20.13 \mathrm{~d}$ & 34.81 & $18.04 \mathrm{c}$ & 38.02 \\
\hline Bakayan extract & $14.58 \mathrm{e}$ & 52.78 & $15.38 \mathrm{c}$ & 47.16 \\
\hline Chilli extract & $23.63 \mathrm{bc}$ & 23.48 & $22.73 \mathrm{~b}$ & 21.92 \\
\hline Thyme extract & $25.26 \mathrm{~b}$ & 18.20 & $23.04 \mathrm{~b}$ & 20.85 \\
\hline Onion extract & $21.68 \mathrm{~cd}$ & 22.80 & $19.04 \mathrm{bc}$ & 34.60 \\
\hline Steward 150 EC & $10.29 \mathrm{f}$ & 66.67 & $10.53 \mathrm{~d}$ & 63.82 \\
\hline Control & $30.88 \mathrm{a}$ & 0.00 & $29.11 \mathrm{a}$ & 0.00 \\
\hline LSD $\mathbf{0 . 0 5}$ & $\mathbf{3 . 2 0 4}$ & - & $\mathbf{4 . 5 8 8}$ & - \\
\hline
\end{tabular}

Means in columns with different letters are significantly different at $p=0.05$ using LSD Test

Table 5. Effect of different botanical extracts and synthetic insecticide on yield on tomato during 2014

\begin{tabular}{|c|c|c|}
\hline Treatments & Yield $\left.\mathbf{( k g ~ h a}^{-\mathbf{1}}\right)$ & \% increase over Control \\
\hline Eucalyptus extract & $8359 \mathrm{~b}$ & 52.34 \\
\hline Bakayan extract & $8076 \mathrm{~b}$ & 47.18 \\
\hline Chilli extract & $7512 \mathrm{c}$ & 36.90 \\
\hline Thyme extract & $6410 \mathrm{~d}$ & 16.82 \\
\hline Onion extract & $7102 \mathrm{c}$ & 29.43 \\
\hline Steward 150 EC & $9564 \mathrm{a}$ & 74.30 \\
\hline Control & $5487 \mathrm{e}$ & - \\
\hline LSD $\mathbf{0 . 0 5}$ & $\mathbf{4 1 7 . 8 9}$ & - \\
\hline
\end{tabular}

Means in columns with different letters are significantly different at $\mathrm{p}=0.05$ using LSD Test

\section{Conclusion and recommendation}

Based on current study, it was concluded that the new chemistry insecticide, Steward 150 EC proved the most effective in controlling the fruit worm infestation and consequently led to better fruit protection with significant increase in tomato production. However, it is more toxic to natural enemies. Hence, the use botanical extracts (bakayan, chilli and onion) is the better alternative to synthetic insecticide as they are cheap, easily available and relatively safe to the natural enemies and other non-target species. Therefore, it is recommended to use different plant based, indigenous botanical insecticides such as eucalyptus, chilli and onion etc. in IPM programs for the sustainable management of $H$. armigera in tomato and other crops.

\section{Authors' contributions}

Conceived and designed the experiments: A Usman, M Shah, Performed the experiments:
MI Ali, Analyzed the data: F Amin, J Sarwar, Wrote the paper: A Usman.

\section{References}

1. Hoffmann H, Hardie D \& Burt J (2007). Tomato pests in the home garden and their control. Dept Agric Australia Garden Note 34: 82-88.

2. Hussain B, \& Bilal S (2007). Efficacy of different insecticide on tomato fruit borer Helicoverpa armigera. J Entomol 4(1): 64-67.

3. Sharma HC (2001). Cotton Bollworm/Legume Pod Borer, Helicoverpa armigera (Hubner) (Noctuidae: Lepidoptera): Biology and Management. Crop Protection. Compendium. Wallingford, CAB International, pp 70.

4. Shaheen N (2008). Is organic forming suitable solution for Pakistan. SDPI Res and News Bull 15(2): 78-81.

5. Husain M (1993). The control of rice borer in Bangladesh. Pestol 8(8): 28-30.

6. Hassan SA (1992). Guideline of side effect of plant protection product on 
Trichogramma chilonis. In guideline for testing the effect of pesticides on beneficial organism. /WPRS Bulletin 105(3): 19-39.

7. Henderson CF \& Tilton EW (1952). Tests with acaricides against the brown wheat mite. J Econ Entomol 48: 157- 161.

8. Usman A, Khan IA, Inayatullah M, Saljoqi AUR \& Shah M (2013). Appraisal of different tomato genotypes against tomato fruit worm (Helicoverpa armigera Hub.) infestation. Pakistan J Zool 45(1): 113119.

9. Ramasubramanian, $\mathrm{T}$ \& Regupathy A (2004). Evaluation of indoxacarb against pyrethroid resistant population of Helicoverpa armigera Hub. J Entomol 1: 21-23.

10. Usman A, Inayatullah M, Sohail K, Shah SF, Usman M, Khan K \& Mashwani MA (2012). Comparing the efficacy of Chrysoperla Carnea (Stephen), neem seed extract and chemical pesticide against tomato fruit worm (Helicoverpa armigera Hubner). Sarhad J Agric 28(4): 611-615.

11. Ramos JM, Lechuga A, Hatem AES \& Osuna EV (2004). Com-o paration of susceptibility of Spodoptera littoralis (Boisduval) and Helicoverpa armigera (Hubner) larvae to spinosad, a natural insecticide. Bol de Sanidad Vegetal Plagas 30(3): 573-580.

12. Abid R \& Cagnieul P (2003). Indoxacarb: a new active insecticidal ingredient against fruit moths. Colloque international tomato sous abri, protection integree agriculture biologique, Avignon, France, pp 188-191.

13. Shi ZH \& Liu SS (1998). Toxicity of insecticides commonly used in vegetable fields to the diamondback moth, Plutella xylostella, and its parasite, Cotesia plutellae, Chinese J Biolog Control 14: 5357.

14. Shi ZH, Guo SJ, Lin WC \& Liu SS (2004). Evaluation of selective toxicity of five pesticides against Plutella xylostella (Lep: Plutellidae) and their side effects against Cotesia plutellae (Hym: Braconidae). Pest Manag Sci 60: 1213-1219.

15. Miller JT (2004). Sustaining The Earth, Sixth Edition, Thompson Learning Inc, California. pp 31-39.

16. Mordue AJ \& Nisbet AJ (2000). Azadirachtin from the neem tree
Azadirachta indica: its actions against insects. Ann Soc Entomol Brasil 29(4): 615-632.

17. Priestley CM, Williamson EM, Wafford KA \& Satelle DB (2003). Thymol, a constituent of thyme essential oils, is a positive modulator of human GABA and a homo-oligosteric GABA receptor from Drosophila melanogaster. Br J Pharmacol 140: 1363-1372.

18. Grafton CEE, Godfrey L D, Chaney WE \& Bentley WJ (2005). Various novel insecticides are less toxic to humans, more specific to key pests. California Agric 59 (1): 29-34.

19. Dhawan AK (2000). Impact of some new insecticides on natural enemy complex of cotton ecosystem. Pestol 24(5): 8-14.

20. Khan SZ, Ullah F, Khan S, Khan MA \& Khan MA (2015). Residual effect of insecticides against different stages of green lacewing, Chrysoperla carnea (Neuroptera: Chrysopidae). J Entomol \& Zool Studies 3(4): 114-119.

21. Sansone CG \& Minzenmayer RR (2000). Impact of new Bollworm insecticides on natural enemies in the Southern rolling plains of Texas. Cotton Insect Research and Control Conference 1104-1105.

22. Nasreen A, Ashfaq $M$ \& Mustafa G (2000). Intrinsic toxicity of some insecticides to egg Parasitoid Trichogramma

Chilonis (Hymeoptera:

Trichogrammatidae). Bull Inst Trop Agric Kyushu Univ 23: 41-44.

23. Mudathir M, \& Basedow T (2004). Field experiments on the effects of neem products on pests and yields of okra Abelmoschus esculentus in the Sudan. Mitteil Deutsch Gesellsch Allgem Angew Ent 14: 407-410.

24. Gowri S, Ramachandrarao G \& Nagalingam B (2002). Impact of neem formulations on Coccinellid predators of okra pest complex. Pestic Res J 14: 242243.

25. Gerald B, \& Frank Z (2005). Tomato. In Rick, F. \& Brian, R. F. (eds) Vegetable Insect Management. Ohion: Meister Media Worldwide Willonghbyr, USA. pp 124-142. 